\title{
United States as proliferation policeman
}

\begin{abstract}
By imposing an economic ban on China in retaliation for the alleged sale of missile parts to Pakistan, the United States has done the right thing, but has gone only half-way towards the goal of limiting the spread of weapons.
\end{abstract}

THE United States has called China's bluff on nuclear arms sales to Pakistan, imposing economic sanctions against China for allegedly selling Pakistan ballistic missile technology in violation of the Missile Technology Control Regime. Taking the principled high ground, as he should, US President Bill Clinton has imposed a ban on sales worth more than $\$ 1$ billion of high technology products ranging from electronic equipment to space technology and military planes. The president has been persuaded by evidence from US intelligence agents that China, despite vigorous denials, has sold missile components to Pakistan. In particular, China is believed to have sold parts for the M-11 missile, with a range of 300 miles and capable of carrying nuclear warheads.

The seriousness of the decision should not be underestimated. It may cost US defence manufacturers as much as $\$ 500$ million a year in sales - and many of those working in the industry may lose their jobs. At a time when employment (or the lack of it) is a crucial issue in the United States, some unpopularity will fall on the president's shoulders. And although the two candidates, George Bush and Bill Clinton, more or less agreed during last year's presidential election campaign that injudicious arms sales should not be used to boost employment, Clinton is now on his own. Yet matters could get worse. If it emerges that Pakistan has been supplied with whole missiles, the administration says that present sanctions will be made still tougher.

Why has Clinton taken all these risks? The Missile Technology Control Regime, to which 23 nations have agreed in various degrees, is meant to halt the spread of nuclear weapons by stopping the spread of their delivery systems. China is not among the signatories, but agreed two years ago to adhere to its conditions, arguing all along that selling missile components to Pakistan was not a violation. But Clinton obviously has in mind the review conference of the Nuclear Non-Proliferation Treaty (NPT), due in the middle of 1995, at which the present members will be required to agree that the treaty should continue. For several months, the United States has been twisting arms, notably in Pakistan and North Korea, in the interests of non-proliferation. It is a good cause that would be made still better if the objectives were more generally understood.

But is it wise that the United States should take this whole burden on its shoulders? Would it not be better that it should take its anxieties about China's trade in missile components to the United Nations, which is in principle as competent to intervene in favour of the NPT as it is in Somalia and Bosnia?
That way, it would be possible to win the compliance of other industrialized nations in favour of a treaty whose continuation is an essential ingredient of a peaceful century ahead. And while China, as a member of the Security Council, would be able to veto proposals for coordinated sanctions, even that might help to clear the air - and rid Clinton of domestic grumbling.

The other question that arises is whether this incident will bring the United States and other industrialized governments to their senses about the sale of conventional arms, apparently to all customers. That baleful trade has strengthened with the ending of the Cold War. Instead of beating arms into ploughshares, arms suppliers are seeking to turn them into cash. That is a crazy and dangerous situation. While it is true that nuclear weapons pose the greatest threat, the most casual recollection of the Gulf War and the more recent horrors in the former Yugoslavia makes plain that vast damage that can be done by conventional weapons, themselves now capable of mass destruction. Restraint in that regard could usefully be part of the package the nuclear powers will have to try to sell to those without weapons in 1995.

\section{All free trade is good}

\section{President Bill Clinton must fight to win agreement to the free-trade pact with Canada and Mexico.}

PRESIDENT Bill Clinton's first vacation from his still-new job may have given him the touch of reflectiveness that the United States needs in a president. That must be everybody's hope. For avoiding the pitfalls of the coming months will require the judicious blend of thought and determination whose lack has kept the president on a knife-edge in his first short spell. And what pitfalls? The immediate answer is the ambitious health-care plan, now partially unveiled and certain to be contentious and preoccupying. But there is a more urgent task: the North American Free Trade Agreement (NAFTA) between Canada, Mexico and the United States, which Clinton's predecessor signed last year and which has since been left swinging in the wind.

Clinton is understandably in a fix about NAFTA, which the Congress has only 80 days to brood about. For one thing, it was not his idea in the first place. For another, it is plain that the treaty will not pass the Congress unless the president backs it with his power and prestige. But it is also plain that 